\title{
EGFR Inhibitor DBPR112
}

National Cancer Institute

\section{Source}

National Cancer Institute. EGFR Inhibitor DBPR112. NCI Thesaurus. Code C153427.

An orally available inhibitor of the epidermal growth factor receptor (EGFR), with potential antineoplastic activity. Upon oral administration, DBPR112 binds to and inhibits the activity of EGFR as well certain mutant forms of EGFR, including EGFR L858R and EGFR T790M. This prevents EGFR-mediated signaling, and may lead to both induction of cell death and inhibition of tumor growth in EGFR-overexpressing cells. EGFR, a receptor tyrosine kinase mutated in many tumor cell types, plays a key role in tumor cell proliferation and tumor vascularization. 